\title{
A FLEXIBILIS HIDRAULIKUS TÖMLŐ KAPACITÁSÁNAK VIZSGÁLATA
}

\author{
Fekete Tamás \\ egyetemi tanársegéd, Miskolci Egyetem, Szerszámgépészeti és Mechatronikai Intézet \\ 3515 Miskolc, Miskolc-Egyetemváros, e-mail: fekete@uni-miskolc.hu \\ Czupy Imre \\ egyetemi docens, Soproni Egyetem, Erdö- és Természeti Eröforrásgazdálkodási Intézet \\ 9400 Sopron, Bajcsy-Zsilinszky utca 4., e-mail: czupy.imre@uni-sopron.hu
}

\begin{abstract}
Absztrakt
A váltakozó áramú hidraulikus rendszerek hidromotorját a hidrogenerátorral a fázistér köti össze. A fázistér feladata a hidrogenerátor által elöállitott hidraulikus energia továbbitása a hidromotor felé. A kutatómunka során a kísérleti berendezés átviteli tulajdonságait két különbözö anyagú fázistérrel is megvizsgáltam. Az egyik esetben a fázisvezetékek merev falú acélcsövekkel, mig a másik esetben rugalmas falú flexibilis csövekkel voltak ellátva. A különbözö anyagból készült fázisterek hatással vannak a rendszer átviteli tulajdonságaira. A merev falú fázisvezetékek helyettesitése rugalmas falú flexibilis fázisvezetékekkel a rendszer kapacitiv ellenállásának megváltozását eredményezi. Ez a változás pedig a kapacitás növekedésével fog járni, ugyanis a merev falú fázisvezeték méretei változatlannak (üzemi körülmények között gyakorlatilag nem változik a mérete) tekinthetöek a rugalmas falú fázisvezetékkel szemben. A kisérlet eredményeként meg fogjuk tudni állapitani, hogy milyen esetben célszerü és lehetséges a flexibilis tömlök használata.
\end{abstract}

Kulcsszavak: váltakozó áramú hidraulikus hajtás, fázistér, kapacitás

\begin{abstract}
The hydromotor of alternating current hydraulic systems is connected to the hydrogenerator by the phase space. The function of the phase space is to transmit the hydraulic energy produced by the hydrogenerator to the hydromotor. During the research work, the transmission properties of the experimental equipment were also examined with two phase spaces of different materials. In one case, the phasepipes were provided with rigid-walled (steel) pipes, while in the other case, flexible-walled pipes. Phase spaces made of different materials affect the transmission properties of the system. Replacing rigid-walled phase conductors with flexible-walled phase conductors results in a change in the capacitive resistance of the system. This change will be accompanied by an increase in capacity, as the dimensions of the rigid-walled phase pipes can be considered unchanged (practically no change in size/diameter under operating conditions) compared to the flexible-walled phase line. As a result of the experiment, we will be able to determine in which case it is expedient and possible to use flexible hoses.
\end{abstract}

Keywords: alternating current hydraulic drive, phasepace, capacity 


\section{Bevezetés}

A hidraulikus hajtásokat két nagy csoportra oszthatjuk; egyenáramú, illetve váltakozó áramú hidraulikus hajtásokra. Az egyenáramú hidraulikus hajtásoknál a folyadék a szivattyú és a munkavégző elemek (pl. hidromotor) között egy irányba áramlik, míg a váltakozó áramú hidraulikus hajtásoknál a hidrogenerátor és a hidromotor között pulzáló mozgást végez. A hajtás müködésének szempontjából meg kell vizsgálni, hogy a flexibilis fázisvezeték nyomás hatására milyen alakváltozást szenved (Runlian et al., 2013), ugyanis ez nem hajtóáramként, hanem veszteségként jelentkezik a rendszerben. A méréseknél használt flexibilis fázisvezeték kialakítását az 0 mutatja.

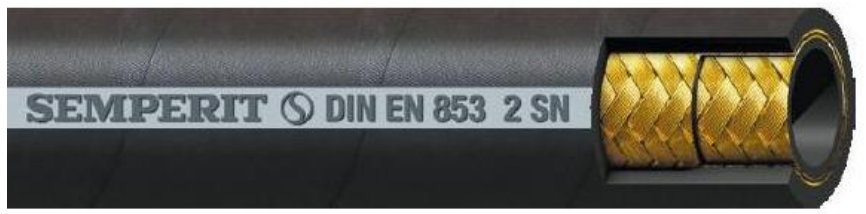

1. ábra. A Semperit DIN EN 8532 2SN DN10 típusú flexibilis hidraulikus vezeték.

A kísérleti berendezésnél felhasznált flexibilis fázisvezeték fizikai jellemzőit az 1. táblázat tartalmazza.

1. táblázat. A Semperit DIN EN $2 S N$ DN10 vezeték föbb paraméterei.

\begin{tabular}{|c|c|c|c|c|c|}
\hline Belső átmérő & Külső átmérő & Munkanyomás & $\begin{array}{c}\text { Repesztési } \\
\text { nyomás }\end{array}$ & Hajlítási sugár & Tömeg \\
\hline $99 \mathrm{~mm}$ & $184 \mathrm{~mm}$ & 330 bar & 1320 bar & $125 \mathrm{~mm}$ & $0,44 \mathrm{~kg} / \mathrm{m}$ \\
\hline
\end{tabular}

A rugalmas fázisvezeték alkalmazása esetén a növekedő belső nyomás hatására a cső átmérője megnő (Erdélyi et al., 2008). Ez nem tekinthetö tisztán ohmos ellenállásnak, mint az elektrotechnikában, ugyanis az ebből keletkező veszteséget a későbbiekben (a nyomás csökkenése során) a rendszer számára visszaadja, így energiatároló (akkumulátor) szerepet tölt be a rendszerben.

\section{Mechanikai vizsgálat}

Szilárdságtani szempontból a cső üzemi nyomásra történő alakváltozása a legfontosabb tényező, hiszen szoros összefüggésben van a rendszer kapacitásával. A kísérleti berendezés hidraulikus vezetékei minden esetben forgásfelületek voltak.

Ebből kifolyólag a továbbiakban csak a belső nyomással terhelt forgásfelületekkel foglalkozunk. Feltételezzük, hogy a folyadék halmazállapotú közeg nyugalomban van, valamint azt, hogy a közeg ideális, tehát belső súrlódása nincs (csúsztató feszültség nem ébred benne), így a nyomás akadálymentesen terjed a fluidumban, $\mathrm{s}$ az edény falára merőlegesen hat.

A szakirodalom az alábbi megállapításokat teszi:

- A $\frac{v}{r}$ (ahol v - a cső falvastagsága, $\mathrm{r}$ - a cső közepes sugara) hányados az egység mellett elhanyagolható;

- az alakváltozások kicsik; 
- az alakváltozások előtt a közepes felületre merőleges egyenesek az alakváltozások közben merölegesek maradnak a megváltozott közepes felületre;

- a nyíró igénybevétel (a $\tau$ feszültségek) az egyensúlyi egyenlettől eltekintve, figyelmen kívül hagyhatóak.

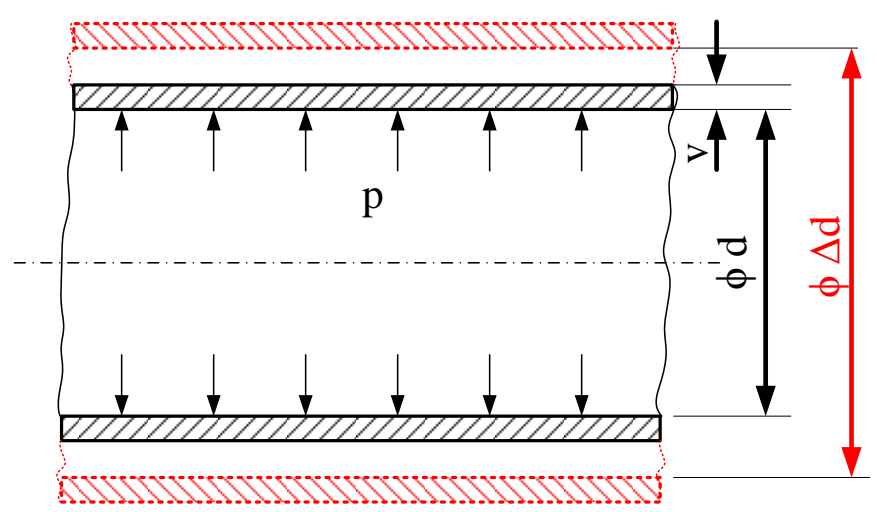

2. ábra. A fázisvezetékben keletkezö nyomás hatására fellépö elméleti alakváltozás.

Az alakváltozási állapotot az $\overline{\varepsilon_{x}}, \overline{\varepsilon_{y}}$ és $\overline{\varepsilon_{z}}$ fajlagos nyúlások határozzák meg. A fenti feltevések alapján:

$$
\begin{aligned}
& \varepsilon_{x}=\frac{z}{\rho}+X=k z+X \\
& \varepsilon_{y}=\frac{u}{r+z}=\frac{u}{r}\left[1-\frac{z}{r}+(\ldots)\right] \approx \frac{u}{r}, \\
& \gamma_{x y}=\gamma_{x z}=\gamma_{y z}=0
\end{aligned}
$$

illetve

$$
\begin{gathered}
\overline{\varepsilon_{x}}=\chi \zeta+\bar{X}, \\
\varepsilon_{y}=\varepsilon .
\end{gathered}
$$

A feltevésekböl az következik tehát, hogy az $\overline{\varepsilon_{y}}$ tangenciális nyúlás a falvastagság mentén közelítően állandó, az $\overline{\varepsilon_{x}}$ hosszirányú nyúlás pedig lineárisan változik.

Amennyiben a készülék (tartály) zárt, akkor hosszirányú, axiális feszültség is keletkezik a forgásfelületben.

A 0 jelöléseivel a $p$ belső nyomással terhelt hengeres tartály véglapjaira ható axiális irányú erő:

$$
F_{a}=\frac{D^{2} \pi}{4} p
$$




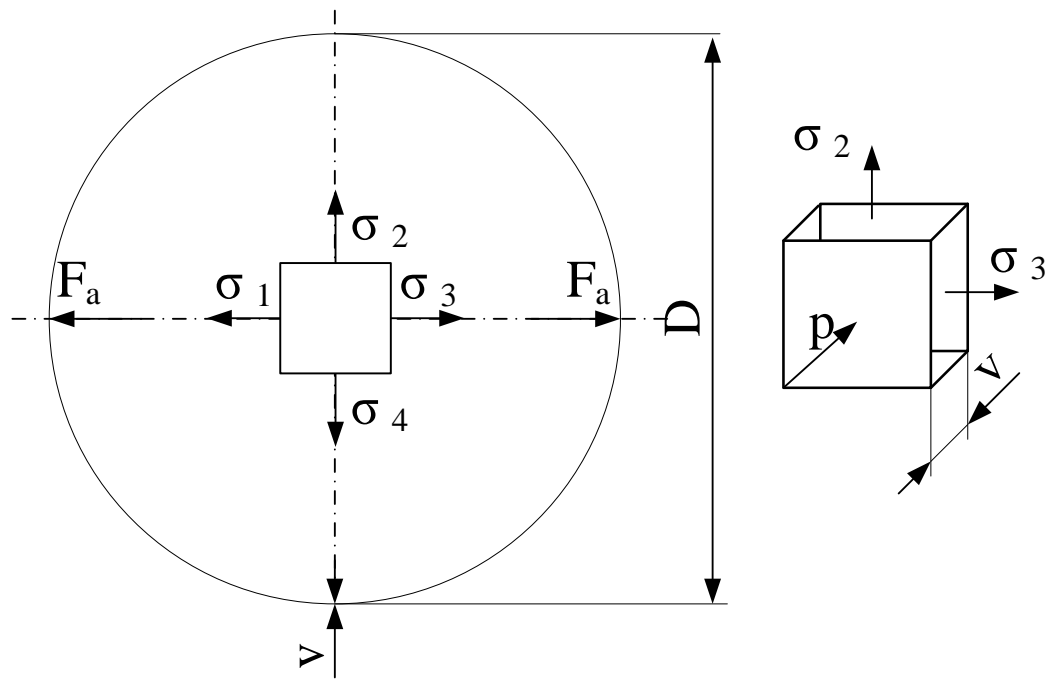

3. ábra. Belsö nyomással terhelt fázisvezeték.

A keresztirányú méretváltozás esetén ismeretes, hogy a húzott rúd a húzóerő irányában megnyúlik, ugyanakkor keresztirányban rövidül.

A próbapálcákkal végzett kísérletek tanúsága szerint a hosszirányú és keresztirányú méretváltozások (fajlagos nyúlások) aránya állandó:

$$
\left|\frac{\varepsilon_{k}}{\varepsilon}\right|=v=a ́ l l,
$$

ahol

- a $v$ arányszám, a Poisson-tényező egyazon anyagminőség mellett állandó, tehát anyagjellemző. Értéke a gyakorlatban 0,25 és 0,4 közötti dimenzió nélküli szám.

A hosszanti és keresztirányú fajlagos nyúlások egymással ellentétesek, ezért:

$$
\varepsilon_{k}=-v \varepsilon
$$

Belátható, hogy a Poisson-tényező nagyságára - a rugalmas tartományon belül - egy felső maximális korláttal rendelkezik. Tekintsünk egy egységnyi oldalélekkel rendelkező elemi kockát, és két szembenálló lapja mentén húzzuk meg. Az elemi kocka a húzás irányában megnyúlik, a rá merőleges két irányban összezsugorodik. Így térfogatváltozására érvényes, hogy:

$$
\Delta v \cong \varepsilon-2 \varepsilon_{k}=\varepsilon(1-2 v)
$$

Közelítésként felhasználtuk, hogy a fajlagos nyúlások kis értéke következtében azok szorzata elhanyagolható. Mivel a húzás miatt a kocka térfogat növekedéssel jár $(\Delta v>0)$, az (7) egyenlet jobb oldalának pozitív értéket kell felvennie, ami csak $v_{\max }<0,5$ esetén lehetséges.

A kísérleti berendezésnél felhasznált fázisvezetékek esetében a hosszirányú (tengellyel párhuzamos) alakváltozás zérusnak vesszük, ugyanis a vezetékek mindkét vége meg van fogva, így kényszer szempontjából úgy kell rá tekinteni, mintha mindkét vége be lenne falazva. 
A fázisvezeték alakváltozását a 0 mutatja.

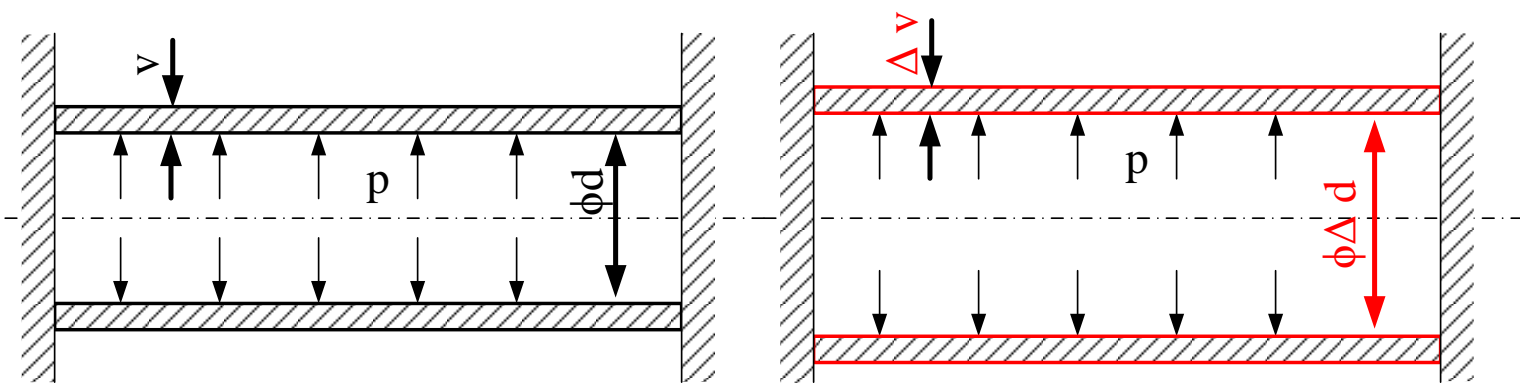

4. ábra. A mindkét végén befalazott fázisvezeték alakváltozásának vázlata.

A keresztirányú alakváltozás mértéke a tehermentes állapothoz képest az üzemi nyomás hatására megnő, ezért csak a keresztirányú méretváltozást kell figyelembe venni. A keresztirányú alakváltozás térfogatváltozással jár, így arra az alábbi összefüggés írható fel:

$$
\Delta V=V_{0} \chi_{k} \Delta p,
$$

ahol

- $\Delta V$, a térfogatváltozás $\left[\mathrm{m}^{3}\right]$,

- $V_{0}$, a kiindulási térfogat $\left[\mathrm{m}^{3}\right]$,

- $\chi_{k}$, rugalmassági modulus reciproka $\left[\frac{1}{G P a}\right]$ és

- $\Delta p$, a nyomásváltozás [bar].

A fázisvezeték jó közelítéssel hengernek tekinthető, így annak térfogata:

$$
V=\left(\frac{D}{2}\right)^{2} \pi h
$$

ahol

- $\quad D$, a hidraulikus tömlő átmérője és

- $\quad h$, a hidraulikus tömlö hossza.

Tehát ebböl adódik, hogy

$$
\left.\begin{array}{l}
V_{0}=\left(\frac{D_{0}}{2}\right)^{2} \pi h \\
\Delta V=\left(\frac{\Delta D}{2}\right)^{2} \pi h
\end{array}\right\},
$$

mert a hidraulikus tömlő hosszát változatlannak tekintjük, ugyanis mindkét vége meg van fogva.

$\mathrm{Az}$

$$
\chi_{k}=\frac{1}{E} \text {, }
$$


ahol

- $\quad E$, rugalmassági modulus, vagy Young-modulus [GPa].

Így a nyomásváltozás hatására a térfogatváltozás az alábbi összefüggéssel határozható meg:

$$
\begin{aligned}
& \Delta V=\Delta p\left(V_{0} \chi_{k}\right) \\
& \left(\frac{\Delta D}{2}\right)^{2} \pi h=\Delta p\left(\left(\frac{D_{0}}{2}\right)^{2} \pi h \cdot \chi_{k}\right) .
\end{aligned}
$$

Majd végül a henger átmérőjének a megváltozása az alábbi képlettel meghatározható:

$$
\Delta D=2 \sqrt{\frac{\Delta p\left(\left(\frac{D_{0}}{2}\right)^{2} \pi h \chi_{k}\right)}{\pi h} .}
$$

Az elméleti vizsgálat után az alakváltozásának mértékét kísérleti úton kétféleképpen is megvizsgáltam. A vizsgálat során három különböző fázisvezetéken végeztem el a méréseket. Ebből kettő azonos típusú tömlő, még a harmadik egy másik féle, de a kialakítását tekintve azonos felépítéssel rendelkezett. A vizsgálat célja, hogy megállapítsam, hogy milyen hatással van a nyomásnövekedés a flexibilis fázisvezeték átmérójének nagyságára.

Az első mérési elrendezést a 0 mutatja. Az egyes mérési pontok helyét a piros pontok jelzik a fehér jelölő szalagokon. A kísérlet elvégzéséhez egy BOSCH Rexroth szervó próbapadot használtunk, aminek képét az 0 mutatja. A méréseket statikus állapotban végeztem el, azaz a kívánt nyomásérték beállítása után, egy elzárószelep segítségével biztosítottam a tömlő állandó nyomásértéken tartását. A hidraulikus tömlőn tizenegy pontot jelöltem ki, és egy adott nyomásérték esetén minden egyes vizsgálati ponton ötször ellenőriztem az átmérő nagyságát. A nyomásértékeket a közel atmoszférikus nyomástól egészen 200 bar-ig változtattam, és így tíz különböző nyomáson végeztem el a kísérletet.

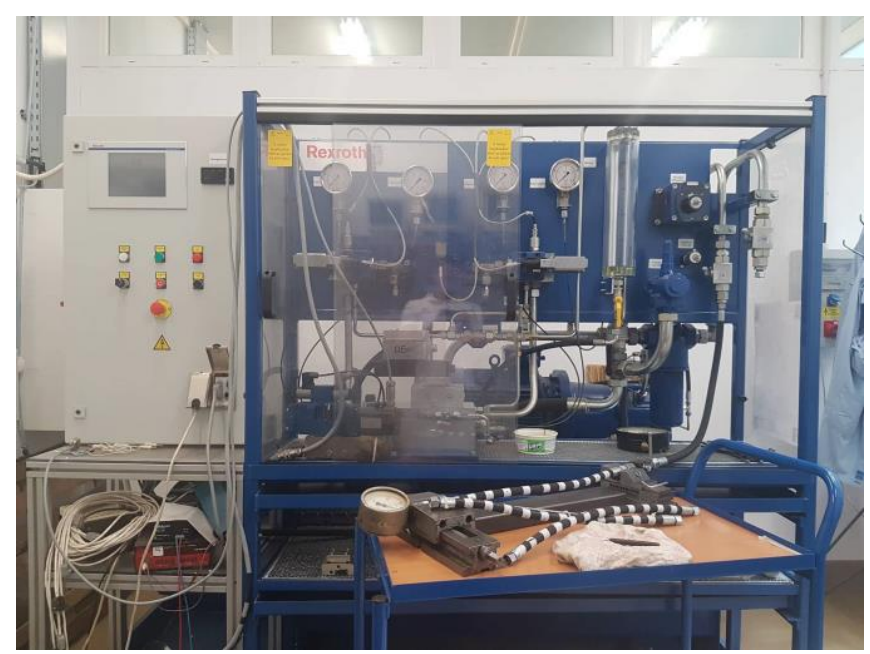

5. ábra. BOSCH Rexroth szervó próbapad.

Az 0 látható szervó próbapad kimeneti oldalára csatlakoztattuk a 0 látható mérési elrendezést. 


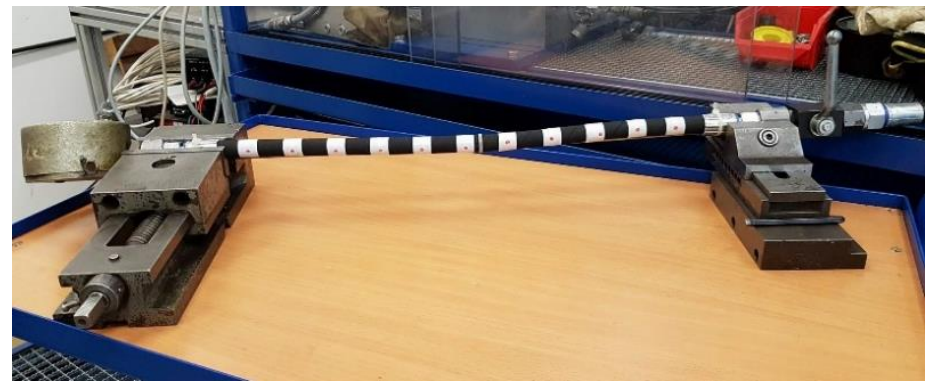

6. ábra. A fázisvezeték vizsgálatának első mérési elrendezése.

A három méréssorozat értékeit a 2. táblázat, 3. táblázat és a 4. táblázat tartalmazzák (a táblázatok egyes celláiban lévő értékek öt mérés átlagértékeit mutatják). A mérés zárt rendszerben történt, így nem volt résolajveszteség.

A 2. táblázat és 3. táblázat azonos anyagú és szerkezeti tulajdonságú (egy hosszú tömlőből vágtunk le kettő azonos hosszúságú csövet) hidraulikus tömlön végzett kísérlet értékeit mutatja.

A 4. táblázat szereplő értékek egy eltérő típusú hidraulikus tömlőből készített kísérlet eredményét mutatják. Az egyes értékek szórásaitól eltekintve megfigyelhető, hogy a legnagyobb alakváltozást a rugalmas fázisvezeték a két végpont között félúton szenvedi el (6. pont). Ezt szemlélteti a 0.

2. táblázat. A hidraulikus tömlö kapacitásának első méréssorozata.

A hidraulikus tömlő kapacitás vizsgálatának átlagértékei 5 ismétlés alapján

\begin{tabular}{|c|c|c|c|c|c|c|c|c|c|c|c|}
\hline $\begin{array}{c}\text { Nyomás } \\
\text { [bar] }\end{array}$ & 1. pont & 2. pont & 3. pont & 4. pont & 5. pont & 6. pont & 7. pont & 8. pont & 9. pont & 10. pont & 11. pont \\
\hline "1" & 18,542 & 18,493 & 18,486 & 18,444 & 18,481 & 18,491 & 18,508 & 18,561 & 18,502 & 18,390 & 18,399 \\
\hline 10 & 18,552 & 18,493 & 18,500 & 18,439 & 18,498 & 18,460 & 18,601 & 18,561 & 18,591 & 18,430 & 18,429 \\
\hline 30 & 18,532 & 18,500 & 18,470 & 18,447 & 18,466 & 18,456 & 18,522 & 18,565 & 18,571 & 18,432 & 18,434 \\
\hline 50 & 18,529 & 18,502 & 18,488 & 18,443 & 18,485 & 18,461 & 18,559 & 18,637 & 18,608 & 18,499 & 18,452 \\
\hline 70 & 18,563 & 18,552 & 18,494 & 18,493 & 18,495 & 18,487 & 18,510 & 18,579 & 18,583 & 18,486 & 18,494 \\
\hline 100 & 18,651 & 18,553 & 18,537 & 18,507 & 18,508 & 18,502 & 18,534 & 18,605 & 18,560 & 18,515 & 18,465 \\
\hline 120 & 18,548 & 18,623 & 18,519 & 18,412 & 18,516 & 18,518 & 18,596 & 18,638 & 18,598 & 18,508 & 18,494 \\
\hline 150 & 18,591 & 18,517 & 18,517 & 18,454 & 18,501 & 18,562 & 18,611 & 18,569 & 18,580 & 18,526 & 18,485 \\
\hline 170 & 18,611 & 18,516 & 18,526 & 18,461 & 18,526 & 18,534 & 18,617 & 18,598 & 18,539 & 18,569 & 18,486 \\
\hline 200 & 18,569 & 18,519 & 18,526 & 18,434 & 18,522 & 18,504 & 18,580 & 18,571 & 18,607 & 18,508 & 18,484 \\
\hline
\end{tabular}

3. táblázat. A hidraulikus tömlö kapacitásának második méréssorozata. 
A hidraulikus tömlő kapacitás vizsgálatának átlagértékei 5 ismétlés alapján

\begin{tabular}{|c|c|c|c|c|c|c|c|c|c|c|c|}
\hline $\begin{array}{c}\text { Nyomás } \\
\text { [bar] }\end{array}$ & 1. pont & 2. pont & 3. pont & 4. pont & 5.pont & 6. pont & 7. pont & 8. pont & 9. pont & 10. pont & 11. pont \\
\hline "1" & 18,639 & 18,697 & 18,690 & 18,658 & 18,748 & 18,696 & 18,705 & 18,766 & 18,687 & 18,683 & 18,677 \\
\hline 10 & 18,639 & 18,655 & 18,698 & 18,672 & 18,753 & 18,747 & 18,711 & 18,746 & 18,691 & 18,666 & 18,594 \\
\hline 30 & 18,665 & 18,701 & 18,732 & 18,666 & 18,756 & 17,819 & 18,666 & 18,711 & 18,590 & 18,622 & 18,577 \\
\hline 50 & 18,662 & 18,658 & 18,634 & 18,651 & 18,726 & 18,729 & 18,773 & 18,725 & 18,696 & 18,538 & 18,532 \\
\hline 70 & 18,618 & 18,676 & 18,707 & 18,654 & 18,747 & 18,753 & 18,701 & 18,705 & 18,654 & 18,650 & 18,627 \\
\hline 100 & 18,692 & 18,721 & 18,787 & 18,705 & 18,747 & 18,667 & 18,684 & 18,670 & 18,681 & 18,658 & 18,497 \\
\hline 120 & 18,663 & 18,685 & 18,697 & 18,703 & 18,806 & 18,809 & 18,711 & 18,722 & 18,734 & 18,698 & 18,623 \\
\hline 150 & 18,689 & 18,689 & 18,702 & 18,667 & 18,764 & 18,799 & 18,720 & 18,705 & 18,697 & 18,675 & 18,645 \\
\hline 170 & 18,651 & 18,630 & 18,691 & 18,700 & 18,733 & 18,760 & 18,680 & 18,719 & 18,702 & 18,689 & 18,625 \\
\hline 200 & 18,671 & 18,632 & 18,679 & 18,677 & 18,728 & 18,818 & 18,692 & 18,734 & 18,735 & 18,703 & 18,641 \\
\hline
\end{tabular}

4. táblázat. A hidraulikus tömlö kapacitásának harmadik méréssorozata (eltérö típusú fázisvezeték)

\begin{tabular}{|c|c|c|c|c|c|c|c|c|c|c|c|}
\hline \multicolumn{10}{|c|}{ A hidraulikus tömlö kapacitás vizs gálatának átlagértékei (új tömló) } \\
\hline $\begin{array}{c}\text { Nyomás } \\
\text { [bar] }\end{array}$ & 1 . pont & 2. pont & 3. pont & 4. pont & 5. pont & 6. pont & 7. pont & 8. pont & 9. pont & 10. pont & 11. pont \\
\hline "1" & 18,703 & 18,653 & 18,647 & 18,703 & 18,722 & 18,648 & 18,660 & 18,714 & 18,707 & 18,657 & 18,634 \\
\hline 10 & 18,692 & 18,644 & 18,643 & 18,692 & 18,654 & 18,650 & 18,658 & 18,727 & 18,614 & 18,649 & 18,645 \\
\hline 30 & 18,680 & 18,660 & 18,652 & 18,715 & 18,654 & 18,657 & 18,642 & 18,731 & 18,663 & 18,649 & 18,694 \\
\hline 50 & 18,668 & 18,644 & 18,643 & 18,695 & 18,745 & 18,637 & 18,677 & 18,730 & 18,634 & 18,689 & 18,649 \\
\hline 70 & 18,686 & 18,652 & 18,663 & 18,665 & 18,698 & 18,625 & 18,645 & 18,745 & 18,618 & 18,677 & 18,654 \\
\hline 100 & 18,680 & 18,664 & 18,685 & 18,711 & 18,681 & 18,668 & 18,694 & 18,729 & 18,618 & 18,660 & 18,641 \\
\hline 120 & 18,681 & 18,653 & 18,655 & 18,751 & 18,705 & 18,726 & 18,680 & 18,744 & 18,628 & 18,728 & 18,668 \\
\hline 150 & 18,671 & 18,680 & 18,661 & 18,702 & 18,741 & 18,714 & 18,667 & 18,735 & 18,637 & 18,669 & 18,724 \\
\hline 170 & 18,685 & 18,663 & 18,666 & 18,730 & 18,741 & 18,715 & 18,715 & 18,760 & 18,655 & 18,686 & 18,717 \\
\hline 200 & 18,696 & 18,676 & 18,700 & 18,710 & 18,738 & 18,728 & 18,693 & 18,739 & 18,619 & 18,687 & 18,658 \\
\hline
\end{tabular}




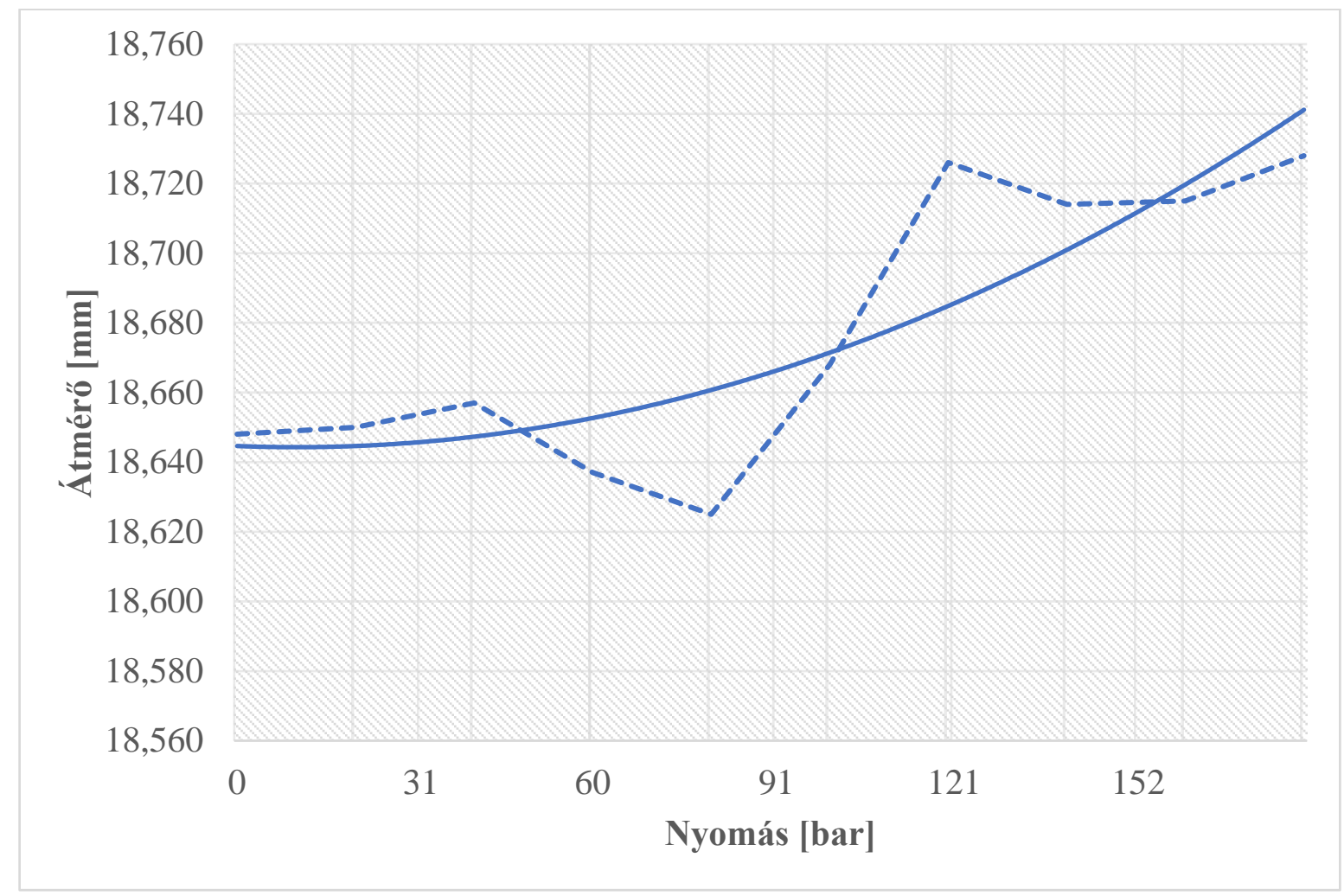

7. ábra. A hidraulikus tömlö középsö keresztmetszete (6. pont) átméröjének változása a nyomás függvényében.

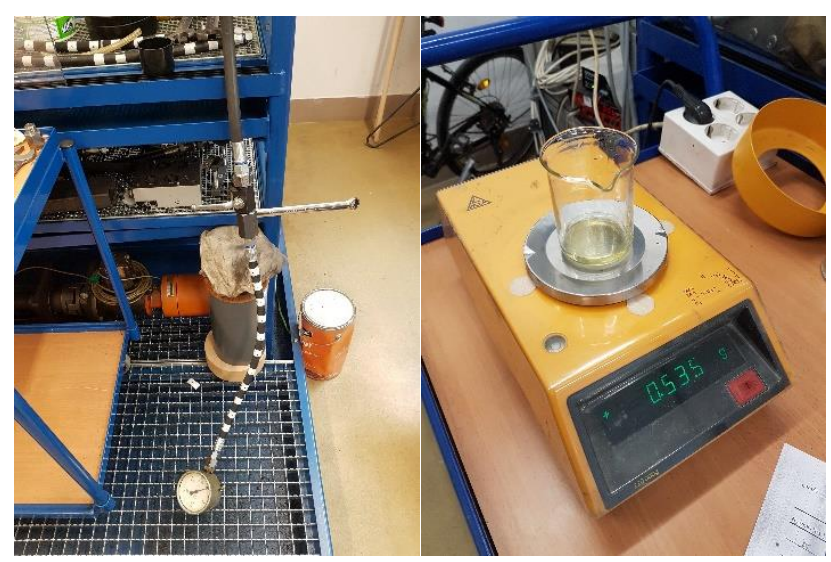

8. ábra. A fázisvezeték vizsgálatának második mérési elrendezése.

A második mérési elrendezést a 0 mutatja. A második mérési elrendezésre azért volt szükség, hogy a fázisvezeték átméröjének esetleges mérési pontatlanságát kiküszöböljük. Ezen elrendezésben a kapacitást úgy mértem meg, hogy készítettem egy csapot, amin keresztül feltöltöttem adott nyomással a vezetéket, majd a kívánt nyomásérték elérése után a csapot elzártam. Ezzel biztosítottam, hogy a kellő 
nyomás eléréséhez szükséges többlet olajmennyiség bent maradjon az elkülönített rendszerben. Ezek után a csap nyomásmentesítő ágát megnyitottam, majd a többletnyomás eléréséhez szükséges olajmennyiséget egy csövön keresztül kiengedtem az elkülönített rendszerből egy mérőedénybe. Majd a mérőedény tömegét egy precíziós mérleg segítségével megmértem. Ezt követően a hidraulikaolaj ismert sürüsége alapján meg tudtam határozni a mennyiségét.

A fázisvezeték különböző nyomásokhoz társuló folyadékmennyiségének tömegeit az 5. táblázat mutatja.

5. táblázat. Az egyes nyomásértékeknél mért többlet folyadékmennyiség.

\begin{tabular}{|c|r|r|r|r|r|r|}
\hline & \multicolumn{5}{|c|}{ Többletnyomást okozó olajmennyiség tömege [g] } \\
\hline $\begin{array}{l}\text { Nyomás } \\
\text { [bar] }\end{array}$ & 1. eset & 2. eset & 3. eset & 4. eset & 5. eset & Átlag \\
\hline 30 & 0,407 & 0,342 & 0,344 & 0,453 & 0,377 & $\mathbf{0 , 3 8 5}$ \\
\hline 50 & 0,503 & 0,532 & 0,536 & 0,529 & 0,517 & $\mathbf{0 , 5 2 3}$ \\
\hline 75 & 0,687 & 0,657 & 0,652 & 0,686 & 0,643 & $\mathbf{0 , 6 6 5}$ \\
\hline 100 & 0,820 & 0,800 & 0,834 & 0,827 & 0,818 & $\mathbf{0 , 8 2 0}$ \\
\hline 150 & 1,142 & 1,129 & 1,130 & 1,088 & 1,061 & $\mathbf{1 , 1 1 0}$ \\
\hline 200 & 1,359 & 1,374 & 1,330 & 1,361 & 1,380 & $\mathbf{1 , 3 6 1}$ \\
\hline
\end{tabular}

Az egyes folyadékmennyiségek tendenciáját a 0 mutatja.

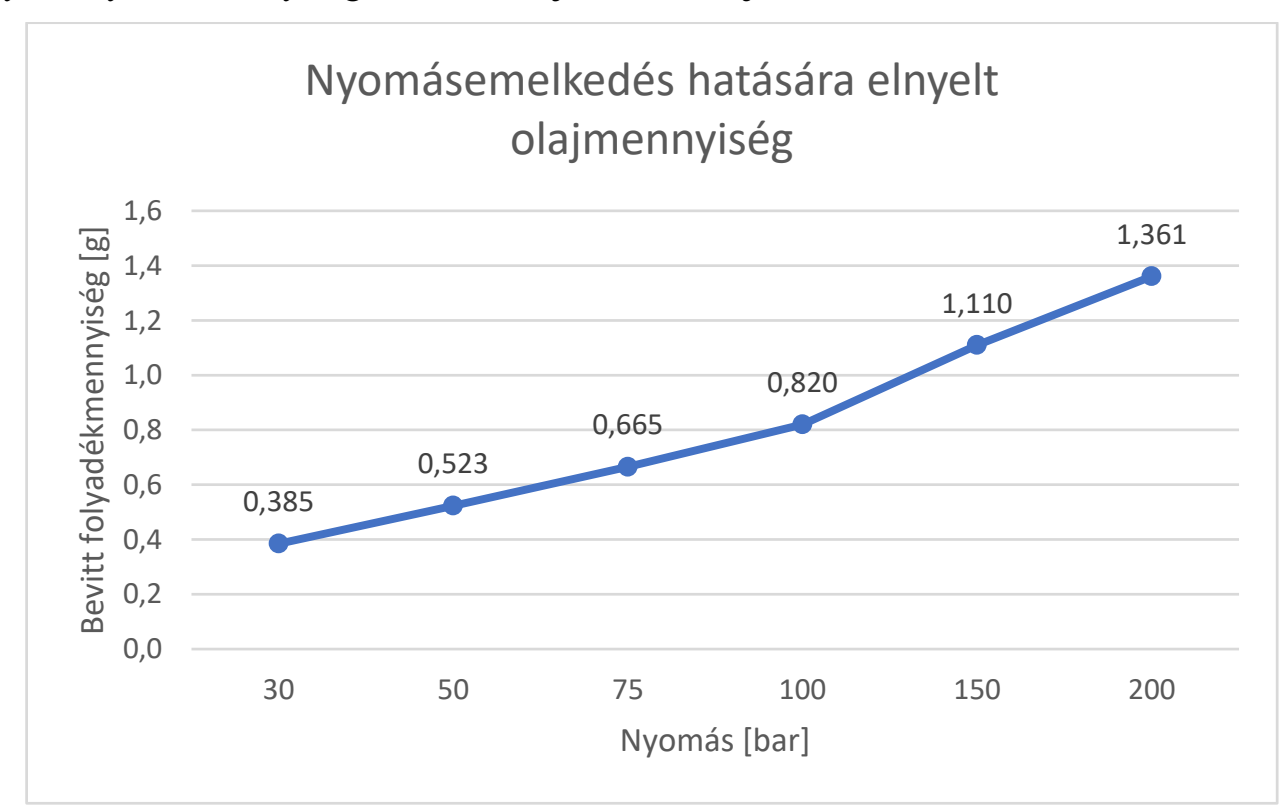

9. ábra. Nyomásemelkedés hatására elnyelt olajmennyiség.

A mérésekből megállapítható, hogy a flexibilis fázisvezeték rendelkezik kapacitív ellenállással. A fázisvezeték átmérőjének változása függ a rendszerben lévő nyomástól, azaz minél nagyobb a belső nyomás, annál nagyobb átmérő érték tartozik hozzá. 


\section{3. Összefoglalás}

A vizsgálatokból egyértelmüen kiderült, hogy a legnagyobb alakváltozást a rugalmas fázisvezeték a két végpont között félúton szenvedi el. A kísérletben alkalmazott csőhossz esetén 200 báros nyomás esetén sem volt számottevő az alakváltozás mértéke, amire az elnyelt olajmennyiségből is lehet következtetni. Érdemes lenne a kísérletet megismételni egy jóval hosszabb tömlő esetében és egy nagy alakváltozással rendelkező fázisvezeték esetében is.

\section{Irodalom}

[1] Runlian, J., Yaohua, W., Chengfei, F., Minajun, D. (2013). The elastic-plastic deformation analysis of the hydraulic pipe under equivalent static loads. IOSR Journal of Mechanical and Civil Engineering (IOSR-JMCE), 9(3), Sep.-Oct., 39-43. e-ISSN: 2278-1684, p-ISSN: 2320334X. https://doi.org/10.9790/1684-0933943

[2] Ponomarjov, Sz. D. (1966). Szilárdsági számitások a gépészetben. Rezgések Ütések. Budapest, Müszaki Könyvkiadó

[3] Erdélyi, J., Fekete, T., Lukács, J. (2008). A kontrakciós henger konstrukciós és müködési tulajdonságai. Pneumatika, hidraulika, hajtástechnika, automatizálás, XII, 3-5.

[4] Fekete, T. (2014). The alternating current synchronous hydraulic drive. Annals of Faculty of Engineering International Journal of Engineering, 12, 235-238.

[5] Fekete, T. (2017). Alternating current hydraulic drive the possibility of applying in the automotive industry. Vehicle and Automotive Engineering, pp 49-57. ISBN978-3-319-51188-7 https://doi.org/10.1007/978-3-319-51189-4_5 